University of Konstanz

Department of Economics

\title{
A Quantitative Model of Sovereign Debt, Bailouts and Conditionality
}

\author{
Fabian Fink and Almuth Scholl
}

Working Paper Series 2011-46

http://www.wiwi.uni-konstanz.de/forschung/ 


\title{
A Quantitative Model of Sovereign Debt, Bailouts and Conditionality*
}

\author{
Fabian Fink \\ University of Konstanz
}

\author{
Almuth Scholl \\ University of Konstanz
}

November, 302011

\begin{abstract}
International Financial Institutions provide temporary balance-of-payment support contingent on the implementation of specific macroeconomic policies. While several emerging markets repeatedly used conditional assistance, sovereign defaults occurred. This paper develops a dynamic stochastic model of a small open economy with endogenous default risk and endogenous participation rates in bailout programs. Conditionality enters as a constraint on fiscal policy. In a quantitative application to Argentina the model mimics the empirical duration and frequency of bailout programs. In equilibrium, conditional bailouts generate high and volatile interest spreads. A Laffer-curve in conditionality reflects the trade-off between fostering fiscal reform and creating incentives for non-compliance.
\end{abstract}

Keywords: sovereign debt, sovereign default, interest rate spread, fiscal policy, bailouts, conditionality

JEL-Codes: $\mathrm{E} 44, \mathrm{E} 62, \mathrm{~F} 34$

\footnotetext{
${ }^{*}$ We are indebted to Patrick Conway who generously shared his excellent data set with us. We thank Stefan Niemann, seminar participants at the University of Konstanz and the German Central Bank for very useful comments and suggestions. We thank Jonas Bürger for excellent research assistance. This research was supported by the junior professor program of the state Baden-Württemberg. The usual disclaimer applies.

Fabian Fink: University of Konstanz, Department of Economics, Postbox D 132, 78457 Konstanz, e-mail: fabian.fink@unikonstanz.de, phone: +49 7531883338.

Almuth Scholl (corresponding author): University of Konstanz, Department of Economics, Postbox D 132, 78457 Konstanz, e-mail: almuth.scholl@uni-konstanz.de, phone: +49 7531883615.
} 


\section{Introduction}

International financial markets have experienced sovereign debt crises throughout history. In times of balance-of-payment problems International Financial Institutions (IFIs) provide temporary financial assistance and require the debtor to meet specific conditions on macroeconomic policy. While over the past 40 years conditionality attached to IFI loans has become increasingly important and countries frequently utilized bailout programs, sovereign defaults occurred on a number of occasions, in particular in emerging market economies. ${ }^{1}$ Empirical evidence indicates that some countries are recidivist borrowers who make repeated and prolonged use of official loans (Bird, Hussain and Joyce (2004), Conway (2007)). In addition, completion rates of conditional bailout arrangements are low (Mussa and Savastano (2000) and Bird (2002)).

This paper develops a dynamic stochastic model of a small open economy that rationalizes these facts. The model features endogenous default risk as well as endogenous participation rates in bailout programs and assumes that conditionality restricts fiscal policy in the recipient country. We analyze the impact of conditional bailouts on sovereign default risk and interest rate spreads and evaluate the effectiveness of conditionality.

Our model builds on the classic contribution by Eaton and Gersovitz (1981) and the recent quantitative sovereign debt literature like Aguiar and Gopinath (2006) and Arellano (2008). We assume a small open economy that is inhabited by a representative household who consumes and works. The government finances unproductive government consumption by raising consumption taxes and by issuing external debt. International financial markets are incomplete and debt contracts are not enforceable. If the country defaults on its outstanding debt it is temporarily excluded from credit markets and faces a loss in output. Risk-neutral foreign lenders incorporate the default risk into their pricing decision and charge a country risk premium. In times of economic crisis, an (unmodeled) IFI provides financial assistance but imposes macroeconomic conditions that restrict non-productive government consumption. In each period, conditional on being in a good credit standing, the government decides whether to fulfill its repayment obligations or to default. Moreover, taking as given the amount of support and the restrictive fiscal target, the government chooses whether to participate in a conditional bailout program.

In a quantitative exercise we apply our model to the Argentine economy and show that our theoretical framework mimics the empirically observed duration and frequency of bailout programs. Our simulations suggest that the presence of IFI interventions make foreign lenders more willing to provide credit to an indebted government since conditional bailout programs provide additional insurance. The government takes advantage of lower interest rates and accumulates larger levels of external debt

\footnotetext{
${ }^{1}$ See Bird (2007) for a detailed discussion of conditionality and Reinhart and Rogoff (2008) for an extensive analysis of sovereign defaults.
} 
leading to high and volatile interest rate spreads in equilibrium. As the simulated moments of the interest rate spread are very close the empirical ones, the model helps to rationalize the disconnect between low historical default probabilities and high average spreads (Arellano (2008)). In addition, our model accounts for the key empirical patterns in emerging market business cycles, in particular procyclical fiscal policy and countercyclical interest rates. ${ }^{2}$

Our analysis of the effectiveness of conditionality suggest that imposing fiscal policy constraints on the provision of financial assistance substantially increases the welfare of the representative household. We vary the intensity of conditionality and highlight the trade-off between fostering fiscal reform and creating incentives for non-compliance. On the one hand, tight constraints on macroeconomic policy limit fiscal mismanagement and promote the recovery of the economy. On the other hand, severe conditionality increases the government's incentives to abandon the arrangement. Enhancing conditionality shortens the duration but increases the frequency of bailouts leading to a higher volatility in the private sector. Our welfare analysis supports the existence of a Laffer-curve suggesting that tightening conditionality does not necessarily improve its effectiveness. ${ }^{3}$

Our paper builds on the recent quantitative sovereign debt literature, in particular Cuadra, Sanchez and Sapriza (2010) who develop a model with endogenous default risk and endogenous fiscal policy to rationalize the empirical fact that fiscal policy tends to move procyclically in emerging markets. Aguiar and Gopinath (2006) and Roch and Uhlig (2011) analyze the impact of bailouts on sovereign default risk where the latter focus on the case of a monetary union. While Aguiar and Gopinath (2006) and Roch and Uhlig (2011) abstract from conditionality, Boz (2011) rationales the quantitative properties of conditional IFI lending within a model of sovereign debt. To model conditionality she assumes that the government acts under a higher rate of time preference leading to a more conservative debt policy. Aguiar and Gopinath (2006), Roch and Uhlig (2011) and Boz (2011) all consider endowment economies and abstract from endogenous fiscal policy. In contrast, our paper develops a production economy and analyzes the dynamic interaction of conditional bailouts, fiscal policy and sovereign default risk. Importantly, to model conditionality we leave the government's preferences unchanged and, instead, impose an additional constraint that restricts the set of fiscal policies. Our study contributes to the literature by focusing on the duration and frequency of bailout programs as well as the effectiveness of conditionality.

Papers that analyze different features in quantitative sovereign debt models are, e.g., Cuadra and Sapriza (2008) and Hatchondo, Martinez and Sapriza (2009) who study the role of political uncertainty, Yue (2010) who focuses on debt renegotiations and Mendoza and Yue (2011) who analyze

\footnotetext{
${ }^{2}$ The empirical cyclical properties of fiscal policy are well documented in Talvi and Vegh (2005), Ilzetzki and Vegh (2008) and Kaminsky, Reinhart and Vegh (2004). Neumeyer and Perri (2005) and Uribe and Yue (2006) analyze the interaction of interest rates and business cycles.

${ }^{3}$ See also Bird (2001a) for a general discussion of the potential existence of a Laffer-curve in conditionality.
} 
the interaction of endogenous output costs and business cycles in emerging markets. Durdu, Nunes and Sapriza (2010) study the role of news shock while Hatchondo and Martinez (2009), Arellano and Ramanarayanan (2010) and Chatterjee and Eyigungor (2011) explore the importance of the maturity structure of bonds.

Our paper is related to the extensive literature that investigates the role of the International Monetary Fund (IMF). In this strand of literature most attention is devoted to the determinants of participation in IMF programs, the macroeconomic effects of IMF supported structural programs as well as on the compliance rates of conditionality. For a discussion of the empirical findings concerning IMF programs we refer to the excellent surveys by Bird (2001b), Joyce (2004) and Bird (2007) and the references therein. Finally, our paper is linked to the foreign aid literature that models conditionality as a limited enforceable contract, e.g., Svensson (2003), Cordella, Dell'Ariccia and Kletzer (2003), Cordella and Dell'Ariccia (2007), Scholl (2009) and Scholl (2011). These studies analyze the properties of optimal self-enforcing contracts in different setups and with different focuses.

The remainder of the paper is structured as follows. In section 2 we describe the empirical characteristics of bailout programs and focus on the frequency and duration as well as the properties of structural conditions. In section 3 we lay out the theoretical framework. Section 4 deals with the calibration, presents the quantitative properties of the model and conducts a welfare analysis to analyze the effectiveness of conditionality. Finally, section 5 concludes.

\section{IMF Programs and Conditionality}

In this section we take the International Monetary Fund (IMF) as a representative of the IFIs, because with 187 member countries it belongs to the most important international intergovernmental organization. According to its Articles of Agreement, the IMF provides temporary financial and technical assistance to member countries that experience balance-of-payments problems. An IMF-supported program typically consists of two parts: IMF lending conditions and IMF conditionality.

IMF lending conditions specify the amount, interest and duration of the bailout program as well as in which tranches the loan is disbursed. The major part of IMF assistance is provided through Stand-ByArrangements (SBA) that typically have a duration of 12-36 months. As reported in table 1 the IMF lending rate is similar to the interest rate of the United States. Since private international financial markets incorporate default risks and charge country risk premia, the IMF lending rate is considerably lower than the country-specific interest rate. Therefore IMF credits involve a grant component for countries that borrow in times of a debt crisis. A further important aspect of IMF lending is discussed by Jeanne and Zettelmeyer (2001) who analyze the empirical repayment history of IMF loans and report rather low default risks on official loans.

The second essential part of an IMF-supported program is conditionality. The IMF provides tem- 
porary financial support only if the recipient government agrees to implement pre-defined economic policies which are designed according to the objectives of the IMF. ${ }^{4}$ Bird (2007) reports that in the last decades the average number of conditions attached to an IMF-supported program has risen indicating that conditionality has become increasingly important. ${ }^{5}$ The Independent Evaluation Office (2007) highlights that during the years 1995-2004 about two-thirds of all structural conditions were nearly equally distributed between the core areas taxation, public expenditure management and the financial sector. According to this evidence adjustments in the public sector belong to the main tasks that have to be undertaken if the IMF intervenes. This finding will guide us when specifying conditionality in our theoretical framework in section 3.

The extensive literature on the role of the IMF emphasizes three phenomena related to conditional IMF-supported programs. First, non-completion of IMF programs is widespread, see, e.g., Mussa and Savastano (2000) and Bird (2002). Second, as Bird et al. (2004) and Conway (2007) point out, some member countries are recidivist borrowers, i.e., they tend to return frequently to the IMF. Third, and related to the second phenomenon, there is evidence on prolonged use of IMF resources calling the temporary nature of IMF lending into question (Bird et al. (2004) and Conway (2007)).

Table 2 and figure 1 illustrate these empirical findings for some selected emerging market countries that had several default episodes. In table 2 we follow Mussa and Savastano (2000) and view the fraction of IMF loans that is actually disbursed relative to the committed under each program as a proxy for completion. Using data provided by Conway (2007), the statistics reveal that several emerging market economies defaulted frequently on their external debt obligations while repeatedly making use of IMF fund resources. During the years from 1976 to 2010 for instance Argentina had 8 IMF-supported economic stabilization programs with an average program duration of approximately 5 quarters. About 37 percent of the programs used less than 50 percent of the committed IMF financing. Brazil, Costa Rica, Ecuador, Peru, Turkey and Uruguay are characterized by similar properties. The left panel of figure 1 shows the the distribution of IMF-supported programs by duration for the countries considered in table 2. 40 percent of all programs last for 4 quarters. Conway (2007) points out that countries tend to repeatedly negotiate economic programs with the IMF that begin just as the previous program has ended. The right panel of figure 1 displays the distribution of successive programs that are interrupted by discontinuation periods of different length. Around 34 percent of programs are consecutive agreements that are interrupted by at most one quarter indicating a high rate of recidivism.

\footnotetext{
${ }^{4}$ Following the IMF's Articles of Agreement conditional lending is required for two reasons: IMF conditionality helps countries to overcome the problems that led to its financial problems and it ensures that IMF loans are repaid. For a broader debate on the rationale for conditionality we refer to Bird (2007).

${ }^{5}$ The Independent Evaluation Office (2007) shows that there seems to be no reduction in the number of conditions after the introduction of the streamlining initiative.
} 


\section{The Model}

\subsection{The Environment}

We consider a small open economy inhabited by a representative household whose preferences are given by

$$
E_{0} \sum_{t=0}^{\infty} \beta^{t} u\left(c_{t}, l_{t}\right)
$$

where $\beta \in(0,1)$ denotes the rate of time preference and $c_{t}$ and $l_{t}$ indicate consumption and labor supply, respectively. The per period utility $u: \mathbb{R}_{+}^{2} \rightarrow \mathbb{R}$ is continuous, twice differentiable in both arguments, strictly increasing in $c$, strictly decreasing in $l$, jointly strictly concave in $c$ and $l$ and satisfies the Inada conditions. The household's budget constraint reads as

$$
\left(1+\tau_{t}\right) c_{t}=y_{t}
$$

where $\tau_{t}$ denotes the consumption tax raised by the government. ${ }^{6}$ Output $y_{t}$ is produced via a constant returns to scale production function $f\left(l_{t}\right), f: \mathbb{R}_{+} \rightarrow \mathbb{R}_{+}$, and is subject to productivity shocks:

$$
y_{t}=z_{t} f\left(l_{t}\right)
$$

Productivity $z_{t} \in \mathcal{Z}$ is assumed to have a compact support, $\mathcal{Z}=[\underline{z}, \bar{z}] \subset \mathbb{R}_{+}$, and to follow a Markov process with a Markov transition function $\mu\left(z_{t+1}, z_{t}\right)$. Preferences of the government are given by

$$
E_{0} \sum_{t=0}^{\infty} \beta^{t}\left[\alpha v\left(g_{t}\right)+(1-\alpha) u\left(c_{t}, l_{t}\right)\right]
$$

where $g_{t}$ denotes unproductive government consumption. The per-period utility $v: \mathbb{R}_{+} \rightarrow \mathbb{R}$ is continuous, twice differentiable, strictly increasing in $g_{t}$, strictly concave in $g_{t}$ and satisfies the Inada conditions. The parameter $\alpha \in(0,1)$ measures the benevolence of the government and can be interpreted as an indicator of the degree of fiscal mismanagement.

The government has access to incomplete international financial markets where it can issue noncontingent one-period bonds $b_{t+1} \in \mathcal{B}=[\underline{b}, \bar{b}] \subset \mathbb{R}$. Let $q_{t}\left(b_{t+1}, z_{t}\right)$ denote the bond price of a financial contract with face value $b_{t+1}$ issued by the government that experiences a productivity shock $z_{t}$. Foreign creditors are risk-neutral and have perfect information about the country's productivity. When the government borrows it receives $q\left(b_{t+1}, z_{t}\right) b_{t+1}<0$ at date $t$ from foreign creditors and promises to repay $b_{t+1}$ at date $t+1$. However, debt contracts are not enforceable and the government can choose to default. We follow Arellano (2008) and assume that the costs of default consist

\footnotetext{
${ }^{6}$ We follow Cuadra et al. (2010) and assume that the government taxes private consumption. This assumption is in line with the empirical findings of Gavin and Perotti (1997) and Talvi and Vegh (2005) who report that tax revenues in Latin America depend heavily on indirect taxes like taxes on goods and services.
} 
of two components. First, the defaulting government is temporarily excluded from international financial markets, i.e., the government stays in financial autarky and is allowed to re-enter international financial markets with an exogenous probability $\theta$. Second, there occur direct output $\operatorname{costs} \delta(z)$ such that $\delta(z) f(l) \leq z f(l)$ holds in financial autarky.

In times of economic crisis, an IFI provide financial assistance, but, in turn, requires the government to implement pre-specified macroeconomic conditions. The government decides whether to enter, to exit or to remain in a bailout program. The government's budget constraint reads as

$$
g_{t}=\tau_{t} c_{t}+b_{t}-q_{t}\left(b_{t+1}, z_{t}\right) b_{t+1}+h_{t} a_{t}
$$

where $h_{t}$ denotes an indicator variable that takes a value of 1 if the government accepts a bailout program and 0 otherwise. If the government makes use of financial assistance, the IFI imposes fiscal conditions that restrict non-productive government consumption in the following way:

$$
\frac{g}{c} \leq \bar{G} \quad \text { if } h_{t}=1
$$

This constraint restricts the size of the public sector and limits fiscal mismanagement. Note that we do not restrict the government's debt policy so that the dynamic pattern of debt remains an endogenous outcome.

As table 1 indicates bailouts are provided as loans below market rates and, therefore, imply transfers to the debtor. We capture this fact by modeling bailouts as grants denoted by $a_{t}$ and assume that the IFI provides financial assistance conditional on the amount of outstanding debt $b_{t}$ and the productivity state $z_{t} .^{7}$ The bailout function is specified as follows

$$
a_{t}= \begin{cases}\Phi\left(b_{t}\right) & \text { for } b_{t} \leq \tilde{b} \text { and } z_{t} \leq \tilde{z} \\ 0 & \text { else }\end{cases}
$$

with $\Phi^{\prime}\left(b_{t}\right)<0$ and $\Phi^{\prime \prime}\left(b_{t}\right) \leq 0 . \tilde{b}$ and $\tilde{z}$ denote threshold values that characterize the bailout policies of the IFI. ${ }^{8}$

\footnotetext{
${ }^{7}$ Here, we follow Aguiar and Gopinath (2006) and assume that also creditors view bailouts as pure transfers and do not internalize that they finance bailouts through tax payments.

${ }^{8}$ As we consider a production economy with endogenous fiscal policy as well as endogenous default risk and endogenous participation rates in bailout programs, modeling bailouts as grants greatly reduces the complexity of the model, in particular in terms of computational time. In contrast, in a stylized endowment economy Boz (2011) explicitly considers IMF-lending as additional state variable that belongs to the choice set of the government. While she assumes that countries have access to IMF-lending at any point in time, we focus on the temporary support offered by IFIs only in times of balance-of-payment crises. She excludes permanent IFI borrowing by assuming that the price of a one-period non-contingent IFI bond is decreasing in the size of the IFI loan. Hence, in times of economic booms the country borrows from private capital markets while in times of recessions IFI borrowing becomes more attractive. In default episodes countries use IFI loans to smooth consumption.
} 


\subsection{Equilibrium}

This section defines and characterize a dynamic recursive equilibrium for our model economy. Given the aggregate state $(b, z)$ the equilibrium is determined by the policy functions of the private sector as well as the public sector and the pricing decision rules for bonds by foreign creditors.

\subsubsection{Private Sector}

In equilibrium the representative household takes the public sector policies as given and chooses private consumption and labor effort by maximizing expected discounted life-time utility (1) subject to the household's budget constraint (2). The optimality condition of the private sector is described by

$$
-\frac{u_{l}(c, l)}{u_{c}(c, l)}=\frac{z f_{l}(l)}{(1+\tau)}
$$

where $u_{c}$ and $u_{l}$ denote the marginal utility of consumption and labor, respectively, and $f_{l}$ refers to the marginal product of labor.

\subsubsection{Public Sector}

In each period, conditional on being in a good credit standing and taking as given the bond price, the realization of the productivity shock and the amount of outstanding bonds, the government decides whether to fulfill its repayment obligations or to default. Moreover, taking as given the amount of financial assistance as well as the fiscal constraint, the government chooses between entering, continuing or exiting a conditional bailout program with the IFI. The government determines its optimal choices by maximizing its preferences (3) subject to the government budget constraint (4), the optimality conditions of the private sector (2) and (7) and, in case of financial assistance, subject to conditionality (5).

Given an outstanding debt amount of $b$ and a technology realization of $z$ let $V^{0}(b, z): \mathcal{B} \times \mathcal{Z} \rightarrow$ $\mathbb{R}$ be the value function when the government has access to international financial markets. The government determines its optimal choices by comparing the value functions of four options:

$$
V^{0}(b, z)=\max \left\{\widehat{V}^{c}(b, z), \widehat{V}^{d}(z), \bar{V}^{c}(b, z), \bar{V}^{d}(z)\right\} .
$$

$\widehat{V}^{c}(b, z): \mathcal{B} \times \mathcal{Z} \rightarrow \mathbb{R}$ denotes the government's value function of honoring its outstanding external debt and staying in the credit market. $\widehat{V}^{d}(z): \mathcal{Z} \rightarrow \mathbb{R}$ is the value function of defaulting on the whole amount of external debt and being punished by a temporary stay in financial autarky and an output loss. $\widehat{V}^{c}(b, z)$ and $\widehat{V}^{d}(z)$ both assume that no financial assistance is provided and the government is unrestricted in designing its fiscal policies. In contrast, $\bar{V}^{c}(b, z): \mathcal{B} \times \mathcal{Z} \rightarrow \mathbb{R}$ and $\bar{V}^{d}(z): \mathcal{Z} \rightarrow \mathbb{R}$ refer to the value functions associated with a bailout program where the government acts subject to 
conditionality. The former is the value function of receiving financial assistance and fulfilling debt obligations while the latter is the value function of defaulting in spite of IFI assistance.

If the government receives no assistance from the IFI and honors its debt obligations, the government does not face any constraints that restricts its fiscal policy choices. The government takes the bond price $q\left(b^{\prime}, z\right)$ as given and solves the following maximization problem:

$$
\widehat{V}^{c}(b, z)=\max _{g, \tau, b^{\prime}, c, l}\left\{\alpha v(g)+(1-\alpha) u(c, l)+\beta \int_{z^{\prime}} V^{0}\left(b^{\prime}, z^{\prime}\right) \mu\left(z^{\prime}, z\right) d z^{\prime}\right\}
$$

subject to

$$
\begin{aligned}
& g=\tau c+b-q\left(b^{\prime}, z\right) b^{\prime}, \\
& (1+\tau) c=z f(l), \\
& -\frac{u_{l}(c, l)}{u_{c}(c, l)}=\frac{z f_{l}(l)}{(1+\tau)} .
\end{aligned}
$$

If, instead, the government defaults on its debt, it relaxes its budget constraint by not repaying its debt but faces costs arising from the temporary exclusion from international financial markets and the direct output loss represented by $\delta(z)$. In this case, the maximization problem is given by:

$$
\widehat{V}^{d}(z)=\max _{g, \tau, c, l}\left\{\alpha v(g)+(1-\alpha) u(c, l)+\beta \int_{z^{\prime}}\left[\theta V^{0}\left(0, z^{\prime}\right)+(1-\theta) \widehat{V}^{d}\left(z^{\prime}\right)\right] \mu\left(z^{\prime}, z\right) d z^{\prime}\right\}
$$

subject to

$$
\begin{aligned}
& g=\tau c, \\
& (1+\tau) c=\delta(z) f(l), \\
& -\frac{u_{l}(c, l)}{u_{c}(c, l)}=\frac{\delta(z) f_{l}(l)}{(1+\tau)} .
\end{aligned}
$$

$\theta$ denotes the exogenous re-entry probability to international financial markets.

In times of an economic crisis, $z_{t} \leq \tilde{z}, b_{t} \leq \tilde{b}$, the IFI provides financial assistance but imposes conditionality in form of restricting unproductive government consumption. In this case, the government compares the costs of conditionality and the benefits of receiving assistance that relaxes the budget constraint. If the government does not default on its debt, the optimal choices are the outcome of the 
following maximization problem, taking grants $a$ as given:

$$
\bar{V}^{c}(b, z)=\max _{g, \tau, b^{\prime}, c, l}\left\{\alpha v(g)+(1-\alpha) u(c, l)+\beta \int_{z^{\prime}} V^{0}\left(b^{\prime}, z^{\prime}\right) \mu\left(z^{\prime}, z\right) d z^{\prime}\right\}
$$

subject to

$$
\begin{aligned}
& g=\tau c+b-q\left(b^{\prime}, z\right) b^{\prime}+a, \\
& (1+\tau) c=z f(l), \\
& -\frac{u_{l}(c, l)}{u_{c}(c, l)}=\frac{z f_{l}(l)}{(1+\tau),} \\
& \frac{g}{c} \leq \bar{G} .
\end{aligned}
$$

If the economic crisis is very severe the government may choose to dishonor its debt obligations although it has made use of conditional financial assistance:

$$
\bar{V}^{d}(z)=\max _{g, \tau, c, l}\left\{\alpha v(g)+(1-\alpha) u(c, l)+\beta \int_{z^{\prime}}\left[\theta V^{0}\left(0, z^{\prime}\right)+(1-\theta) \widehat{V}^{d}\left(z^{\prime}\right)\right] \mu\left(z^{\prime}, z\right) d z^{\prime}\right\}
$$

subject to

$$
\begin{aligned}
& g=\tau c+a, \\
& (1+\tau) c=\delta(z) f(l), \\
& -\frac{u_{l}(c, l)}{u_{c}(c, l)}=\frac{\delta(z) f_{l}(l)}{(1+\tau)}, \\
& \frac{g}{c} \leq \bar{G} .
\end{aligned}
$$

In the following, we characterize the government's default and conditionality policies by a default set and a bailout set. Let $\mathcal{D}(b)$ denote the set of productivity realizations $z \in \mathcal{Z}$ for which default is optimal given an asset level of $b$ and let $\mathcal{H}(b)$ denote the set of productivity realizations $z \in \mathcal{Z}$ for which a bailout program is optimal given an asset level of $b$. With the definition

$$
\begin{aligned}
& \bar{V}(b, z)=\max \left\{\bar{V}^{c}(b, z), \bar{V}^{d}(z)\right\}, \\
& \widehat{V}(b, z)=\max \left\{\widehat{V}^{c}(b, z), \widehat{V}^{d}(z)\right\},
\end{aligned}
$$

the government's bailout policy is characterized by

$$
h(b, z)= \begin{cases}1 & \text { if } \widehat{V}(b, z)<\bar{V}(b, z) \\ 0 & \text { else. }\end{cases}
$$

The bailout set is given by $\mathcal{H}(b)=\{z \in \mathcal{Z}: h(b, z)=1\}$. Similarly, to specify the default set we define

$$
\begin{aligned}
V^{c}(b, z) & =\max \left\{\widehat{V}^{c}(b, z), \bar{V}^{c}(b, z)\right\}, \\
V^{d}(z) & =\max \left\{\widehat{V}^{d}(z), \bar{V}^{d}(z)\right\} .
\end{aligned}
$$


The government's default policy is characterized by

$$
d(b, z)= \begin{cases}1 & \text { if } V^{c}(b, z)<V^{d}(z) \\ 0 & \text { else }\end{cases}
$$

implying the default set $\mathcal{D}(b)=\{z \in \mathcal{Z}: d(b, z)=1\}$.

\subsubsection{Foreign Creditors}

The government, conditional on being in a good credit standing, is able to borrow from or to save to a large number of identical infinitely lived risk-neutral foreign creditors. Foreign creditors have perfect information about the productivity realization and they can borrow or lend from international capital markets at the constant risk-free rate $r_{f}$. Foreign creditors incorporate the government's default probability $\lambda\left(b^{\prime}, z\right)$ in their pricing decision and maximize expected profits $P$ :

$$
P=\max _{b^{\prime}}\left\{-q b^{\prime}+\frac{1-\lambda\left(b^{\prime}, z\right)}{1+r_{f}} b^{\prime}\right\} .
$$

The endogenous default probability $\lambda\left(b^{\prime}, z\right)$ is related to the default set according to

$$
\lambda\left(b^{\prime}, z\right)=\int_{\mathcal{D}\left(b^{\prime}\right)} \mu\left(z^{\prime}, z\right) d z^{\prime} .
$$

Competitive risk-neutral pricing implies the following bond price function

$$
q\left(b^{\prime}, z\right)=\frac{1-\lambda\left(b^{\prime}, z\right)}{1+r_{f}} .
$$

This optimality condition states that bond prices lie in the closed interval $q \in\left[0,\left(1+r_{f}\right)^{-1}\right]$. The sovereign's interest rate is given by the relation $r^{c}\left(b^{\prime}, z\right)=1 / q\left(b^{\prime}, z\right)-1$ while the interest rate spread is described by $s\left(b^{\prime}, z\right)=r^{c}\left(b^{\prime}, z\right)-r_{f}$.

\subsubsection{Recursive Equilibrium}

Given the specification of the decision problems of the agents in the economy, in the following, we define the recursive equilibrium.

Definition 1. The recursive equilibrium for this small open economy is defined as

1. a set of policy functions for household's consumption $c(b, z)$ and labor time $l(b, z)$,

2. a set of policy functions for the government's debt policy $b^{\prime}(b, z)$, government consumption $g(b, z)$ and tax policy $\tau(b, z)$,

3. the default set $\mathcal{D}(b)$ and the bailout set $\mathcal{H}(b)$, 
4. the price function for bonds $q\left(b^{\prime}, z\right)$,

5. a set of value functions $V^{0}(b, z), \widehat{V}^{c}(b, z), \widehat{V}^{d}(z), \bar{V}^{c}(b, z)$ and $\bar{V}^{d}(z)$

such that

1. taking as given the government policies household's consumption $c(b, z)$ and labor time $l(b, z)$ satisfy the optimality condition (7) and the household's budget constraint (2),

2. taking as given the bond price function $q\left(b^{\prime}, z\right)$, the optimal policies of the household, the amount of financial assistance a as well as conditionality described by constraint (5), the government's policy functions $b^{\prime}(b, z), g(b, z), \tau(b, z)$, the default set $\mathcal{D}(b)$ and the bailout set $\mathcal{H}(b)$ solve (8), (9), (10), (11) and (12),

3. bond prices $q\left(b^{\prime}, z\right)$ fulfill equation (14) such that risk-neutral foreign creditors earn zero expected profits.

\section{Quantitative Analysis}

\subsection{Data}

In our quantitative analysis we apply our model to Argentina to study the interaction of conditional bailout programs, fiscal policy and default episodes. Argentina is a typical emerging market economy that frequently made use of IMF conditional lending facilities but experienced several sovereign debt crises in the past, see table 2 and Beim and Calomiris (2001) and Reinhart and Rogoff (2008). Most recently, in 2001, Argentina defaulted on its public external debt after having accumulated large fiscal deficits in the 1990s. At the beginning of the 1990s Argentina's economy was characterized by high inflation rates and economic stagnation. To achieve price stability, the convertibility regime was adopted that pegged the peso to the US Dollar. The loss of monetary policy increased the importance of fiscal policy to react to adverse shocks, however, Argentina was characterized by fragile political institutions, weak fiscal discipline and a severe dependence on external borrowing (Independent Evaluation Office (2004)). According to Mussa (2002) the inability of the government to maintain a sustainable fiscal policy was the the primary root of this debt crisis. In early 2000 the IMF approved a three-year Stand-By-Arrangement in which structural fiscal reform and fiscal consolidation were the main program goals. But, as the Independent Evaluation Office (2004) emphasizes, the conditional bailout program was not successful in promoting economic recovery and lowering interest rates. In December 2001 the fifth review of the program was not approved because of substantial discrepancies between the IMF staff and Argentina's authorities on the prospects for restoring the health of the public finances (Independent Evaluation Office (2004)). On December 23 Argentina defaulted on its public external debt. 
The first column of table 4 summarizes business cycle statistics for the Argentine economy. The quarterly real series are taken from Argentina's Ministry of Economics and Finance (MECON). They are seasonally adjusted and range from 1993.1 to 2010.4. For the consumption tax $\tau$ we use an inflation tax as a proxy due to lack of adequate data. The inflation tax is constructed as $\tau=\frac{\pi}{1+\pi}$ where $\pi$ denotes CPI inflation. ${ }^{9}$ The interest rate series is the JP Morgan Emerging Markets Bond Index (EMBI Global). External debt is measured by public and publicly guaranteed external debt which is obtained from the World Bank for 1980-2009. The trade balance is given as a percentage of output. Output, private and government consumption are in logs. All series are detrended using the Hodrick-Prescott filter with a smoothing parameter of 1600.

As reported by Aguiar and Gopinath (2006) and Arellano (2008) output is negatively correlated with the interest rate spread. The mean interest rate spread is 12.54 percent and the volatility amounts to 8.28 percent. Consumption is more volatile than output and the trade balance is countercyclical. The tax rate is negatively correlated with output which is in line with the empirical study of Talvi and Vegh (2005).

To evaluate the grant component of IMF credits we employ the difference between the lending rate of the IMF and the country-specific interest rate charged by foreign creditors:

$$
a_{t}=s_{t} b_{t}^{\mathrm{IMF}}
$$

$s_{t}$ denotes the interest rate spread and $b_{t}^{\mathrm{IMF}}$ refers to the use of IMF credit taken from the International Financial Statistics database. Using equation (15) to quantify the grant component rests on the perception that countries repay IMF loans which is in line with the low empirical default risks on official debt reported by Jeanne and Zettelmeyer (2001). However, since countries are usually completely separated from private financial markets in times of economic crisis, equation (15) seems to be a conservative estimate of the grant component of official loans. In contrast, Aguiar and Gopinath (2006) assume that the total amount of IMF credit is given as a grant abstracting from the fact that countries need to repay IMF loans. In comparison to equation (15) this a high estimate of the grant component of bailout programs. In our quantitative exercise we assume intermediate values.

Table 4 reveals that the grant component based on equation (15) is negatively correlated with the ratio of government to private consumption. This is reflected by the mean value of $\frac{g}{c}$ that is lower in times of positive IMF credits than otherwise. In our subsequent analysis we interpret this finding as the outcome of structural conditions that are imposed on the provision of financial assistance.

\footnotetext{
${ }^{9}$ Talvi and Vegh (2005) argue that in developing and emerging market countries tax rates are often based on consumption taxes. Thus, a inflation tax as a proxy for tax rates seems to be appropriate.
} 


\subsection{Functional Forms and Calibration}

To calibrate the model to the Argentine economy we specify functional forms and choose parameter values. Table 3 summarizes the set of parameters and indicates whether the parameter values are chosen based on the sovereign debt literature, estimated from the data or calibrated to match model statistics to the data.

We employ the following per-period utility functions:

$$
\begin{aligned}
u(c, l) & =\frac{\left(c-\frac{l^{1+\psi}}{1+\psi}\right)^{1-\gamma}}{1-\gamma}, \\
v(g) & =\frac{g^{1-\gamma}}{1-\gamma}
\end{aligned}
$$

where $\gamma>0$ denotes the parameter of relative risk aversion and $\frac{1}{\psi}$ is the intertemporal labor elasticity. Note that this specification implies that the marginal rate of substitution between private consumption and labor is independent of consumption. We follow Mendoza (1991), Neumeyer and Perri (2005) and Cuadra et al. (2010) and set $\frac{1}{\psi}$ equal to 2.22. The parameter of relative risk aversion is set to 2 . The quarterly world risk-free interest rate $r_{f}$ is set to 1 percent which is a standard value in quantitative business cycle studies.

The preference parameter $\alpha$ that specifies the weight on unproductive government consumption is set to 0.495 to match the empirically observed average ratio of government consumption to private consumption of 20.26 percent. If the government enters a bailout program with an IFI $\frac{g}{c}$ is restricted to $\bar{G}=0.19$ which corresponds to the empirical mean value in times of positive IMF credits, see first column of table 4.

As in Cuadra et al. (2010) the production function is assumed to be linear in labor, $f(l)=l$. We follow Arellano (2008) and assume that in case of default the government is hit by asymmetric output costs:

$$
\delta(z)= \begin{cases}\eta E(z) & \text { if } z>\eta E(z) \\ z & \text { else }\end{cases}
$$

with $\eta \in(0,1)$. We set the default penalty $\eta$ equal to 0.975 and assume that the rate of time preference $\beta$ takes the value 0.91 . The parameterizations of $\beta$ and $\eta$ are set to match a default probability of 5 percent ${ }^{10}$ and an average debt service on external debt to GDP ratio (public and publicly guaranteed) of 2.90 percent. The probability $\theta$ of re-entering financial markets is set to 0.17 which is in line with values that have been used in previous studies. ${ }^{11}$

\footnotetext{
${ }^{10}$ Argentina experienced default episodes in 1951, 1956, 1982, 1989 and 2001.

${ }^{11}$ Aguiar and Gopinath (2006) set $\theta$ to 0.10 while Arellano (2008) choose 0.282.
} 
We assume that the financial benefits of a bailout programs are linear in the outstanding amount of foreign assets:

$$
a=\Phi(b)= \begin{cases}-\phi b & \text { for } b \leq \tilde{b} \text { and } z \leq \tilde{z} \\ 0 & \text { else }\end{cases}
$$

where $\tilde{b}=0$ and $\tilde{z}=1 .{ }^{12}$ If the interest rate spread is used to calculate the empirical grant component according to equation (15), it amounts to 8 percent of external debt in the year 2001. If instead the grant component is assumed to be equal to the total amount of IMF credit, it takes a value of 20 percent of external debt. In our benchmark calibration we assume an intermediate value and set $\phi=0.14$. In our sensitivity analysis we vary $\phi$ within the interval $[0.08 ; 0.20]$.

Productivity shocks are assumed to follow an AR(1) process:

$$
\log \left(z_{t}\right)=\rho_{z} \log \left(z_{t-1}\right)+\varepsilon_{t}
$$

with $\varepsilon_{t}$ is i.i.d. $N\left(0, \sigma_{\varepsilon}^{2}\right)$. The parameters of the productivity shock process are set as to match the autocorrelation and standard deviation of Argentine real GDP series.

\subsection{Results}

In this section we study the quantitative predictions of our benchmark model economy. To highlight the impact of conditional bailout programs on default risk and fiscal policy, we facilitate a comparison with a model economy in which no IFI is present. ${ }^{13}$ Table 4 reports the cyclical properties of the simulated times series as well as statistics on the duration and frequency of the use of conditional bailout programs. The business cycle statistics are based on average values over 1000 simulations of 160 quarters. The simulated series are detrended using the Hodrick-Prescott filter with a smoothing parameter of 1600 .

Table 4 shows that the benchmark economy matches the key properties of the Argentine data. The model predicts 11 programs in 40 years with an average duration of 3.73 quarters which mimics the empirically observed frequency and duration of bailout programs quite well. A comparison of the cyclical properties of the benchmark model and the model without an IFI reveals that conditional bailout programs increase the mean and the volatility of the interest rate spread. As the simulated moments are very close to the empirical ones, the model helps to rationalize the disconnect between low historical default probabilities and high and volatile interest rate spreads (Arellano (2008)). The model can account for the key business cycle statistics in emerging market economies. In particular, consumption is more volatile than output and the trade balance is countercyclical. As in Arellano

\footnotetext{
${ }^{12}$ We verified the robustness of the results with respect to these choices and conducted only minor differences.

${ }^{13}$ The model without an IFI is similar to the one in Cuadra et al. (2010).
} 
(2008) and Aguiar and Gopinath (2006), the economy is more borrowing constrained in times of recessions because of higher interest rate spreads. In line with Cuadra et al. (2010) tax rates behave countercyclically reflecting the fact that in bad economic times borrowing becomes more expensive so that the government finances its consumption mainly by taxing its citizens. The model accounts well for the empirical fact that public consumption is less procyclical than private consumption. However, the model overstates the volatility of public consumption and understates the volatility of the tax rate. Moreover, as in most quantitative models of sovereign debt, external debt as a share of GDP is far too low.

To explore the economic mechanisms behind these results, the left panel of figure 2 plots the bond price $q\left(b^{\prime}, z\right)$ as a function of assets $b^{\prime}$ for two types of productivity shocks $z$. It is evident that, first, the bond price charged by foreign creditors is an increasing function in foreign assets. For very low levels of debt the government always repays and the bond price is equal to the inverse of the risk-free rate. Higher levels of foreign debt make repayment less attractive and default incentives rise. Since foreign creditors incorporate the default probability in their pricing decision they charge higher risk premia. Second, the bond price is an increasing function in the productivity shock. A country that experiences an adverse economic shock is less able to service its external debt obligations. The higher probability of default lowers bond prices in times of recessions. Third, the bond price is greater in the presence of an IFI. The intuition is straightforward: Since foreign creditors anticipate IFI support in times of economic crisis, they are more willing to provide credit to indebted countries and charge lower interest rates. These findings are reflected in the borrowing function $b^{\prime}(b, z)$ shown in the right panel of figure 2. Compared to the model without an IFI, default occurs at higher levels of foreign debt. Consequently, for a given level of debt the government borrows more at lower interest rates. The simulation results presented in table 4 reveal that in equilibrium the government takes advantage of lower interest rates and accumulates larger levels of external debt if an IFI is present. In turn, higher levels of debt lead to higher default probabilities and greater and more volatile interest rate spreads.

As discussed in section 2, the empirical literature emphasizes that some countries are recidivist borrowers who make repeated and prolonged use of official loans, see Bird et al. (2004), Bird (2002) and Conway (2007). To study the quantitative predictions of our model with respect to the duration and the recidivism in the use of IFI assistance, the left panel of figure 3 shows the distribution of conditional bailout programs by their duration. In the right panel, we calculate the distribution of successive programs that are interrupted by discontinuation periods of different length. Thereby, we exclude programs that are interrupted by default episodes. Figure 3 reveals that the majority of programs runs for a short time period. Around 70 percent of all programs have a duration between one and four quarters. Our model predicts that the mass of successive programs have discontinuation 
periods of few quarters. More than 40 percent of all consecutive arrangements are interrupted by only one quarter indicating a high rate of recidivism. The shapes of the distributions are broadly in line with the empirical distributions plotted in figure 1. However, our theoretical framework overstates the number of programs that last for only few quarters.

To understand the dynamic impact of conditional bailouts and the determinants of entries and exits, we collect all conditional bailout arrangements that have a duration of 3 quarters. ${ }^{14}$ Figure 4 plots the average pattern of the macroeconomic variables over time. Quarter 1 denotes the period before the government enters the conditional bailout program while in quarter 5 the program is abandoned. The shaded area refers to the time in conditionality. We distinguish two cases: First, the government exits the conditional bailout program to be sovereign and unrestricted in its fiscal policies (solid line). Second, the government exits the arrangement by defaulting on its external debt (dashed line). The simulated time paths reveal that a country enters a conditional bailout program with an IFI if it is indebted and hit by an adverse productivity shock such that the interest rate spread is high. In exchange for the financial support the recipient government fulfills the restriction on its public consumption and reduces its external debt. The tax cut has a stimulating effect on output and consumption. As long as the country is sufficiently indebted, the benefits of the financial assistance outweigh the costs of conditionality and the government continues to participate in the bailout program. The government decides to leave the conditional program to return to sovereignty if a series of favorable productivity shocks helps the economy to recover. Interest rate spreads decrease and the cost of conditionality arising from restrictive public consumption becomes too high such that the government leaves the bailout program. In contrast, the country abandons the conditional bailout arrangement by default if it is hit by a series of adverse shocks repressing production and private consumption and increasing the interest rate spread. These findings are in line with the view that a combination of weak fiscal discipline and adverse external shocks contributed to Argentina's crisis in 2001 (Independent Evaluation Office (2004)).

\subsection{Policy Implications}

The empirical evidence on low rates of compliance with conditionality and the repeated and persistent use of official financial assistance motivated the IMF 'streamlining' initiative introduced in 2000 . The aim was to improve the completion, implementation and effectiveness of conditionality by making it more parsimonious (Bird (2009)). In this section we employ our theoretical framework to analyze the macroeconomic impact of different intensities of conditionality and discuss policy implications.

To evaluate the effectiveness of conditionality and to derive policy implications we calculate the impact of conditional bailout programs on the welfare of the representative household. We compare

\footnotetext{
${ }^{14}$ The findings are similar for arrangements that have a shorter or longer duration.
} 
the lifetime utility in the model economy with an IFI with the lifetime utility in the model economy without an IFI and use compensating variations to formulate differences. We express the welfare gain in terms of percentage deviations in certainty-equivalence consumption. Let $\bar{c}$ and $\bar{l}$ denote the average consumption and labor effort in the model economy where no IFI is present. Moreover, let $c_{t}^{*}$ and $l_{t}^{*}$ denote the optimal decision rules at date $t$ in the model economy with an IFI. The compensation parameter $\Delta^{h}$ solves:

$$
\sum_{t=0}^{\infty} \beta^{t} u\left(\left(1+\Delta^{h}\right) \bar{c}, \bar{l}\right)=E_{0} \sum_{t=0}^{\infty} \beta^{t} u\left(c_{t}^{*}, l_{t}^{*}\right) .
$$

For comparison, we report the welfare gain of the government by calculating the compensation parameter $\Delta^{g}$ that solves

$$
\sum_{t=0}^{\infty} \beta^{t}\left[\alpha v(\bar{g})+(1-\alpha) u\left(\left(1+\Delta^{g}\right) \bar{c}, \bar{l}\right)\right]=E_{0} \sum_{t=0}^{\infty} \beta^{t}\left[\alpha v\left(g_{t}^{*}\right)+(1-\alpha) u\left(c_{t}^{*}, l_{t}^{*}\right)\right],
$$

where $\bar{g}$ denotes the average government consumption in the model where no IFI is present while $g_{t}^{*}$ refers to the optimal decision rule at date $t$ in the model economy with an IFI.

In the first row of figure 5 we vary the intensity of conditionality and plot the resulting welfare gains of the household and the government. To analyze the effectiveness of conditionality, we focus on the welfare of the representative household. Our welfare calculations reveal that conditional bailouts generate substantial welfare gains of up to 1.96 percent measured in certainty-equivalent consumption units. Our model predicts a Laffer-curve as the pattern of the household's welfare gain is humpshaped implying that enhancing conditionality does not necessarily improve its effectiveness. ${ }^{15}$ If conditionality is too strong such that the government does not make use of IFI grants the welfare gains are obviously zero. If instead conditionality is too weak such that financial assistance is unconditionally provided, the household benefits from an increase in certainty-equivalent consumption of 0.85 percent. These findings suggest that the design of conditionality has quantitatively sizeable implications for the effectiveness of bailout programs.

Turning to the government, it is evident that the welfare gains are decreasing in the intensity of conditionality. Clearly, the government benefits most from unconditional bailouts that generate a welfare gain of 4.14 percent of certainty-equivalent consumption.

The model predictions show that there is a trade-off between fostering efficient economic policies and creating incentives for non-compliance. If the government's cost of tighter fiscal constraints outweighs the benefit of the financial assistance, non-implementation is a likely outcome limiting the effectiveness of conditionality. It turns out that our benchmark calibration is very close to the maximum of the Laffer-curve. To explore the mechanisms of conditionality in greater detail, table 4

\footnotetext{
${ }^{15}$ Bird (2001a) argues verbally, but without any formal model, that such a Laffer curve in conditionality exists.
} 
reports the cyclical properties of the simulated times series as well as statistics on the duration and frequency of bailout programs for 'weak' conditionality, $\bar{G}=0.195$, and 'strong' conditionality, $\bar{G}=$ 0.185. 'Optimal' conditionality refers to the peak of the Laffer-curve. The business cycle statistics show that enhancing conditionality has two effects. On the one hand, stricter fiscal constraints reduce the distortion generated by fiscal mismanagement resulting in stronger reductions in the ratio of public to private consumption, lower average shares of public external debt and reduced interest rate spreads. On the other hand, enhancing conditionality makes bailout programs less attractive for the recipient government so that shorter average program durations generate a higher volatility in the private sector and greater default risks. The two opposing effects of fostering fiscal reform and creating incentives for abandoning a conditional arrangement generate a u-shape in the volatility of production and an inverted $\mathrm{u}$-shape in the average interest rate spread.

In the second row of figure 5 we vary the degree of financial assistance of conditional bailout programs which is measured by the parameter $\phi$. Welfare gains are increasing in the amount of financial support because of two reasons. First, higher grants allow to reduce the external debt burden so that the interest rate spread decreases. Second, raising the financial benefit makes bailout programs more attractive to the government and increases the likelihood that fiscal constraints are implemented. In turn, the effectiveness of conditionality is improved, however, at the cost of providing greater financial assistance.

\section{Conclusions}

In this paper we have developed a dynamic stochastic model of a small open economy to analyze the connections between sovereign default, bailouts and fiscal policy. Our theoretical framework features endogenous default risk as well as endogenous participation rates in bailout programs and assumes that conditionality restricts fiscal policy. The model helps to rationalize three empirical facts. First, there is considerable recidivism and persistence in the use of third-party assistance. Second, in spite of conditionality, sovereign defaults occur. Third, average interest rate spreads are high and volatile in emerging market economies.

Our findings suggest that conditional bailouts increase sovereign default risks as foreign lenders are more willing to provide credit to indebted countries. To evaluate the effectiveness of conditionality we have performed a detailed welfare analysis. Our model predicts that imposing conditions on the provision of bailouts generates sizeable welfare gains. However, there is a trade-off between promoting fiscal reform and creating incentives for non-compliance so that enhancing conditionality shortens the duration of bailout programs but increases recidivism. Our welfare analysis supports the existence of a Laffer-curve implying that tightening conditionality does not necessarily improve its effectiveness. 
In light of the recent European debt crisis this paper points out the importance of analyzing the dynamic interactions of bailouts and default risks to deepen our understanding of the effectiveness of conditionality. In this context it seems to be particularly interesting to analyze the connection between bailouts, conditionality and political turnovers. Moreover, it may be promising to study the participation in bailout programs as a joint decision process of the debtor and the IFI. While in this paper we have taken the policies of the IFI as exogenously given, modeling the IFI as an endogenous decision-maker requires the specification of a rationale for conditionality and the definition of the objectives of the IFI. All these questions are, however, left for future research. 


\section{A Numerical Algorithm}

The model is solved by using value function iteration. The numerical algorithm builds on Hatchondo, Martinez and Sapriza (2010) and employs cubic spline interpolations so that optimal policies are chosen from a continuous set and productivity realizations are allowed that do not lie on the grid. We approximate the equilibrium as the equilibrium of the finite-horizon economy and iterate simultaneous on the value and the bond price functions.

Given our preference specification the household's optimality condition (7) yields optimal labor supply as a function of the tax rate $\tau$ :

$$
l=\left(\frac{z}{1+\tau}\right)^{\frac{1}{\psi}} .
$$

Equation (18) and the budget constraints (2) and (4) allow us to express optimal private and government consumption as functions of the decision variables $b^{\prime}$ and $\tau$.

The following algorithm is used to solve the model. We define evenly distributed grid vectors for bond holdings $b \in[\underline{b}, \bar{b}]$ and productivity realizations $z \in[\underline{z}, \bar{z}]$. Let $\widehat{V}_{(0)}^{c}(b, z), \widehat{V}_{(0)}^{d}(z), \bar{V}_{(0)}^{c}(b, z), \bar{V}_{(0)}^{d}(z)$ denote the initial guesses for the value functions. For every grid point $(b, z) \in[\underline{b}, \bar{b}] \times[\underline{z}, \bar{z}]$ and given the initial guesses $\widehat{V}_{(0)}^{c}(b, z), \widehat{V}_{(0)}^{d}(z), \bar{V}_{(0)}^{c}(b, z), \bar{V}_{(0)}^{d}(z)$ we first find candidate values for $\tau_{(0)}$ and $b_{(0)}^{\prime}$ by employing a global search procedure. These candidate values are then taken as initial guesses for the FORTRAN optimization routine BCPOL from the IMSL library to find $\tau_{(0)}$ and $b_{(0)}^{\prime}$ via (9), (10), (11) and (12), where $V_{(0)}^{0}(b, z)$ satisfies equation (8). Given the initial guess, equations (13) and (14) determine the the default probability $\lambda_{(0)}\left(b_{(0)}^{\prime}, z\right)$ and the bond price function $q_{(0)}\left(b_{(0)}^{\prime}, z\right)$, respectively. Expected continuation values are computed using gauss-hermite quadrature points and weights. To evaluate the expected continuation values for policies and productivity realizations that do not lie on the grid we employ cubic spline interpolations using the FORTRAN CSDEC routine from the IMSL library. The solutions found at each grid point are used to update the value functions $\widehat{V}_{(1)}^{c}(b, z), \widehat{V}_{(1)}^{d}(z), \bar{V}_{(1)}^{c}(b, z), \bar{V}_{(1)}^{d}(z)$. We iterate until the value functions converge. 


\section{References}

Aguiar, M. and Gopinath, G.: 2006, Defaultable Debt, Interest Rates and the Current Account, Journal of International Economics 69, 64-83.

Arellano, C.: 2008, Default Risk and Income Fluctuations in Emerging Economies, The American Economic Review 98(3), 690-712.

Arellano, C. and Ramanarayanan, A.: 2010, Default and the Maturity Structure in Sovereign Bonds, mimeo, Federal Reserve Board Minneapolis .

Beim, D. O. and Calomiris, C. W.: 2001, Emerging Financial Markets, McGraw-Hill Book Co.

Bird, G.: 2001a, IMF Programmes: Is There A Conditionality Laffer Curve?, World Economics 2(2), 29-49.

Bird, G.: 2001b, IMF Programs: Do They Work? Can They be Made to Work Better?, World Development 29(11), 1849-1865.

Bird, G.: 2002, The Completion Rate of IMF Programmes: What We Know, Don't Know and Need to Know, The World Economy 25, 833-847.

Bird, G.: 2007, The IMF: A Bird's Eye View of its Role and Operations, Journal of Economic Surveys 21(4), 683-745.

Bird, G.: 2009, Reforming IMF Conditionality, World Economics 10(3), 81-104.

Bird, G., Hussain, M. and Joyce, J.: 2004, Many Happy Returns? Recidivism and the IMF, Journal of International Money and Finance 23, 231-251.

Boz, E.: 2011, Sovereign Default, Private Sector Credits, and the IFIs, Journal of International Economics 83, 70-82.

Chatterjee, S. and Eyigungor, B.: 2011, Maturity, Indebtedness, and Default Risk, The American Economic Review (forthcoming) .

Conway, P.: 2007, The Revolving Door: Duration and Recidivism in IMF Programs, Review of Eocnomics and Statistics 89(2), 205-220.

Cordella, T. and Dell'Ariccia, G.: 2007, Budget Support Versus Project Aid: A Theoretical Appraisal, The Economic Journal 117, 205-220. 
Cordella, T., Dell'Ariccia, G. and Kletzer, K. M.: 2003, Conditional Aid, Sovereign Debt, and Debt Relief, Research Workshop Macroeconomic Challenges in Low Income Countries .

Cuadra, G., Sanchez, J. M. and Sapriza, H.: 2010, Fiscal Policy and Default Risk in Emerging Markets, Review of Economic Dynamics 13, 452-469.

Cuadra, G. and Sapriza, H.: 2008, Sovereign Default, Interest Rates and Political Uncertainty in Emerging Markets, Journal of International Economics 76, 76-88.

Durdu, C. B., Nunes, R. and Sapriza, H.: 2010, News and Sovereign Default Risk in Small Open Economies, International Finance Discussion Papers, Board of Governors of the Federal Reserve System 997.

Eaton, J. and Gersovitz, M.: 1981, Debt with Potential Repudiation: Theoretical and Empirical Analysis, The Review of Economic Studies 48(2), 289-309.

Gavin, M. and Perotti, R.: 1997, Fiscal Policy in Latin America, in B. Bernanke and J. Rotemberg (eds), NBER Macroeconomics Annual 1997, Volume 12, The MIT Press.

Hatchondo, J. C. and Martinez, L.: 2009, Long-Duration Bonds and Sovereign Defaults, Journal of International Economics 79, 117-125.

Hatchondo, J. C., Martinez, L. and Sapriza, H.: 2009, Heterogenous Borrowers in Quantitative Models of Sovereign Default, International Economic Review 50(4), 1130-1151.

Hatchondo, J. C., Martinez, L. and Sapriza, H.: 2010, Quantitative Properties of Sovereign Default Models: Solution Methods Matter, Review of Economic Dynamics 13, 919-933.

Ilzetzki, E. and Vegh, C. E.: 2008, Procyclical Fiscal Policy in Developing Countries: Truth or Fiction?, NBER Working Paper 1419.

Independent Evaluation Office: 2004, The IMF and Argentina, 1991-2001, Washington, DC: International Monetary Fund.

Independent Evaluation Office: 2007, Structural Conditionality in IMF-Supported Programs, Washington, DC: International Monetary Fund.

Jeanne, O. and Zettelmeyer, J.: 2001, International Bailouts, Moral Hazard and Conditionality, Economic Policy 16(33), 409-432.

Joyce, J.: 2004, The Adoption, Implementation and Impact of IMF Programs: A Review of the Evidence., Comparative Economic Studies 46, 451-467. 
Kaminsky, G. L., Reinhart, C. and Vegh, C. E.: 2004, When It Rains, It Pours: Procyclical Capital Flows and Macroeconomic Policies, NBER Macroeconomics Annual 19, 1-53.

Mendoza, E.: 1991, Real Business Cycles in a Small Open Economy, The American Economic Review 81, 797-818.

Mendoza, E. and Yue, V. Z.: 2011, A General Equilibrium Model of Sovereign Default and Business Cycles, The Quarterly Journal of Economics (forthcoming) .

Mussa, M.: 2002, Argentina and the Fund: From Triumph to Tragedy, Institute for International Economics.

Mussa, M. and Savastano, M.: 2000, The IMF Approach to Economic Stabilization, in B. Bernanke and J. Rotemberg (eds), NBER Macroeconomics Annual 1999, Volume 14, The MIT Press, pp. 79128.

Neumeyer, P. A. and Perri, F.: 2005, Business Cycles in Emerging Economies: The Role of Interest Rates, Journal of Monetary Economics 52(2), 345-380.

Reinhart, C. and Rogoff, K.: 2008, This Time is Different: Eight Centuries of Financial Folly, Princeton University Press.

Roch, F. and Uhlig, H.: 2011, The Dynamics of Sovereign Debt Crises and Bailouts, mimeo, University of Chicago .

Scholl, A.: 2009, Aid Effectiveness and Limited Enforceable Conditionality, Review of Economic Dynamics 12(2), 377-391.

Scholl, A.: 2011, Debt Relief for Poor Countries: Conditionality and Effectiveness, mimeo, University of Konstanz .

Svensson, J.: 2003, Why Conditional Aid Does Not Work and What Can be Done About It?, Journal of Development Economics 70(2), 381-402.

Talvi, E. and Vegh, C. A.: 2005, Tax Base Variability and Procyclical Fiscal Policy in Developing Countries, Journal of Development Economics 78, 156-190.

Uribe, M. and Yue, V. Z.: 2006, Country Spreads and Emerging Countries: Who Drives Whom?, Journal of International Economics 69, 6-36.

Yue, V. Z.: 2010, Sovereign Default and Debt Renegotiations, Journal of International Economics 80, 176-187. 
Table 1: Interest Rates: IMF vs. U.S. Treasury Bonds

\begin{tabular}{cccccc}
\hline \hline & IMF & \multicolumn{3}{c}{ U.S. Treasury bonds } & EMBI Global \\
& & 2-year & 3-year & 5-year & \\
\hline $1990-1999$ & 5.75 & 5.77 & 5.97 & 6.30 & 14.03 \\
$2000-2010$ & 3.44 & 3.06 & 3.29 & 3.74 & 8.68 \\
\hline
\end{tabular}

Notes: Data are taken from the IMF database and Datastream. The interest rate of the IMF is the IMF's Adjusted Rate of Charge. The EMBI Global time series starts in 1997.

Table 2: Fraction of IMF Loans Actually Disbursed, 1976-2010

\begin{tabular}{|c|c|c|c|c|c|c|c|c|}
\hline \multirow[b]{2}{*}{$x \in$} & \multicolumn{6}{|c|}{ Number of arrangements } & \multirow{2}{*}{$\begin{array}{l}\text { Duration } \\
\text { Mean (Med) } \\
\text { (Quarters) }\end{array}$} & \multirow{2}{*}{$\begin{array}{l}\text { Number of } \\
\text { Defaults } \\
1900-2010\end{array}$} \\
\hline & {$[0,0.25)$} & {$[0.25,0.50)$} & {$[0.50,0.75)$} & {$[0.75,1.0)$} & 1 & $N$ & & \\
\hline Argentina & 1 & 2 & 3 & 1 & 1 & 8 & $5.25(5.11)$ & 5 \\
\hline Brazil & 0 & 1 & 0 & 2 & 0 & 3 & $8.85(6.90)$ & 7 \\
\hline Costa Rica & 5 & 1 & 1 & 1 & 1 & 9 & $5.01(4.92)$ & 6 \\
\hline Ecuador & 3 & 1 & 1 & 0 & 2 & 7 & $4.97(4.35)$ & 7 \\
\hline Mexico & 0 & 1 & 1 & 0 & 1 & 3 & $6.97(6.10)$ & 3 \\
\hline Peru & 2 & 1 & 0 & 1 & 0 & 4 & $4.54(4.15)$ & 6 \\
\hline Turkey & 1 & 2 & 0 & 3 & 1 & 7 & $7.19(5.36)$ & 5 \\
\hline Uruguay & 7 & 2 & 0 & 1 & 2 & 12 & $5.27(4.35)$ & 6 \\
\hline All & 19 & 11 & 6 & 9 & 8 & 53 & $5.68(5.01)$ & \\
\hline
\end{tabular}

Notes: Statistics refer to IMF Stand-By Arrangements. $x$ denotes the fraction of total IMF loans disbursed. It is calculated as the fraction of drawings actually made relative to committed IMF resources for each arrangement. The table is constructed following Mussa and Savastano (2000) and using data from the data set in Conway (2007). The number of default events are taken from Reinhart and Rogoff (2008).

Table 3: Benchmark Calibration

\begin{tabular}{llll}
\hline \hline Risk aversion & $\gamma$ & 2 & literature \\
Time preference & $\beta$ & 0.91 & calibration \\
Labor elasticity & $\frac{1}{\psi}$ & 2.22 & literature \\
Preference weight & $\alpha$ & 0.495 & calibration \\
Conditionality & $\bar{G}$ & 0.19 & calibration \\
Bailout & $\phi$ & 0.14 & data \\
Risk free rate & $r_{f}$ & 0.01 & literature \\
Re-entry probability & $\theta$ & 0.17 & literature \\
Default penalty & $\eta$ & 0.975 & calibration \\
Productivity & $\rho_{z}$ & 0.85 & calibration \\
& $\sigma_{\varepsilon}$ & 0.0138 & calibration \\
\hline \hline
\end{tabular}


Table 4: Business Cycle Statistics

\begin{tabular}{lcccccc}
\hline \hline & $\begin{array}{c}\text { Argentine } \\
\text { Data }\end{array}$ & $\begin{array}{c}\text { Benchmark } \\
\text { Model }\end{array}$ & $\begin{array}{c}\text { No } \\
\text { IFI }\end{array}$ & $\begin{array}{c}\text { Strong } \\
\text { Conditionality }\end{array}$ \\
\hline$\sigma(y)$ & 4.09 & 4.09 & 5.18 & 4.22 & 4.12 & 4.19 \\
$\sigma(s)$ & 8.28 & 7.16 & 3.58 & 6.70 & 7.00 & 6.48 \\
$\sigma(c) / \sigma(y)$ & 1.15 & 1.04 & 1.04 & 1.05 & 1.04 & 1.03 \\
$\sigma(g) / \sigma(y)$ & 0.53 & 1.76 & 1.25 & 1.77 & 1.76 & 1.75 \\
$\sigma(n x / y) / \sigma(y)$ & 0.39 & 0.20 & 0.12 & 0.19 & 0.20 & 0.21 \\
$\sigma(\tau) / \sigma(y)$ & 0.48 & 0.23 & 0.10 & 0.24 & 0.23 & 0.22 \\
\hline & & & & & & \\
$\rho(c, y)$ & 0.98 & 0.98 & 0.99 & 0.98 & 0.98 & 0.98 \\
$\rho(g, y)$ & 0.59 & 0.74 & 0.96 & 0.66 & 0.75 & 0.81 \\
$\rho(n x / y, y)$ & -0.91 & -0.41 & -0.58 & -0.33 & -0.41 & -0.47 \\
$\rho(\tau, y)$ & -0.41 & -0.14 & -0.50 & -0.19 & -0.12 & -0.07 \\
$\rho(s, y)$ & -0.69 & -0.26 & -0.45 & -0.17 & -0.28 & -0.35 \\
$\rho(a, g / c)$ & -0.30 & -0.50 & - & -0.62 & -0.52 & -0.22 \\
\hline & & & & & & \\
$E(s)$ & 12.54 & 12.04 & 5.20 & 11.64 & 12.03 & 10.39 \\
$E(g / c)$ & 20.26 & 20.26 & 21.72 & 20.36 & 20.24 & 20.2 \\
$E(g / c), I_{a>0}$ & 18.97 & 18.79 & - & 18.26 & 18.76 & 19.32 \\
$E(b / y), I_{d \neq 1}$ & - & -5.96 & -4.14 & -5.57 & -5.95 & -6.61 \\
\hline & & & & & & \\
Mean Duration & 5.25 & 3.73 & - & 2.72 & 3.66 & 4.67 \\
Mean No. of Programs & 8 & 11.26 & - & 12.55 & 11.43 & 10.48 \\
Default Prob. (in \%) & 5.00 & 5.00 & 2.88 & 4.99 & 5.03 & 4.70 \\
\hline \hline
\end{tabular}

Notes: The simulation results are averages over 1000 simulations whereas each simulation has a sample size of 160 quarters. The standard deviations are reported in percentages. All series are HP-filtered with a smoothing parameter of 1600 . 'Strong' conditionality refers to $\bar{G}=0.185$; 'weak' conditionality refers to $\bar{G}=0.195$. 'Optimal' conditionality refers to the welfare maximizing value of $\bar{G}$. $y$ denotes production, $c$ and $g$ are private and public consumption, respectively. $\tau$ refers to the tax rate while $b$ denotes public debt. $n x$ is the trade balance and $a$ the grant component of IFI support. $s$ denotes the interest spread. $E(b / y), I_{d \neq 1}$ refers to the mean value of debt if default episodes are excluded. 

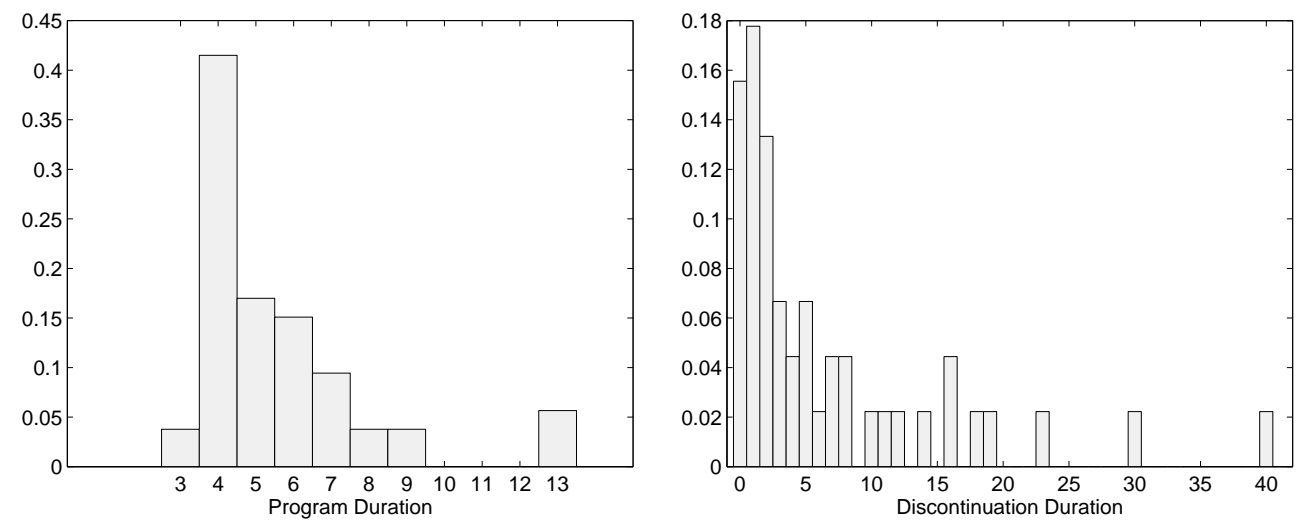

Figure 1: Empirical Distribution of IMF Programs; The figure uses the data set provided by Conway (2007) and refers to IMF Stand-By Arrangements. Horizontal axis: quarters; vertical axis: frequency.
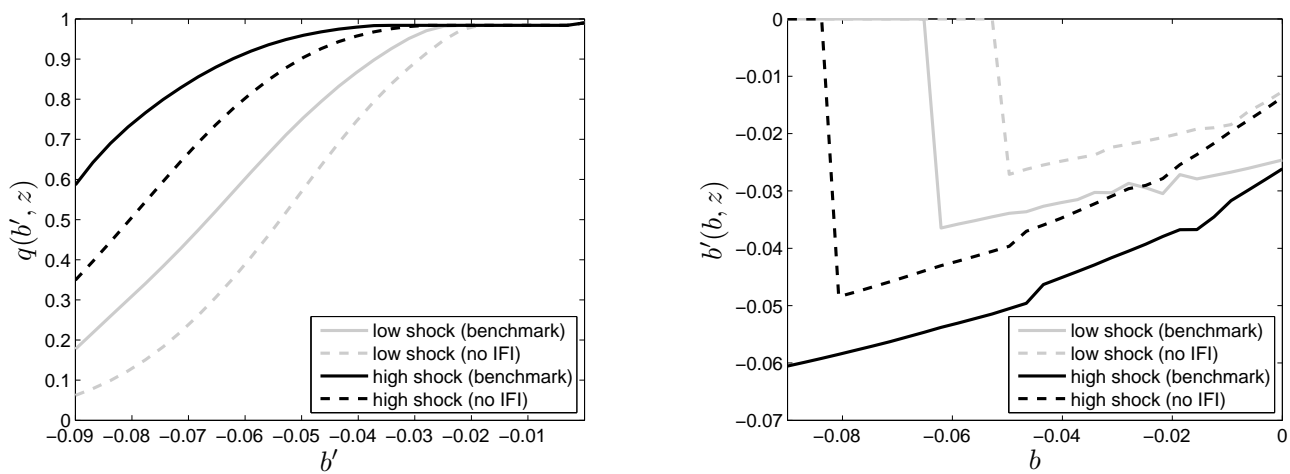

Figure 2: Policy Functions; Policy functions are based on the benchmark calibration.
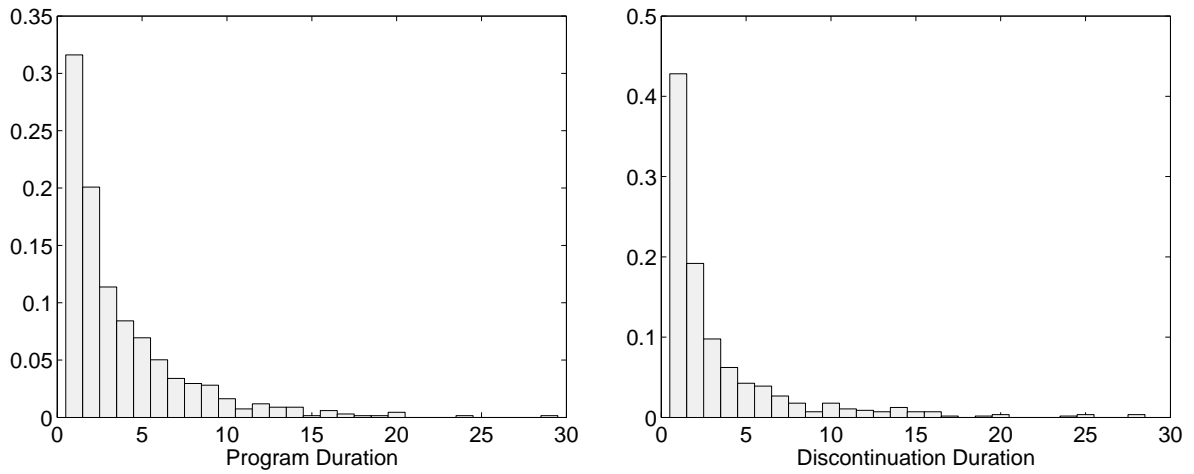

Figure 3: Distribution of Bailout Programs; Horizontal axis: quarters; vertical axis: frequency. The distributions refer to the benchmark calibration. 
Productivity

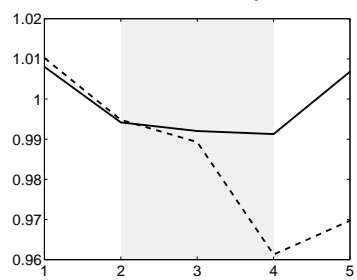

Consumption

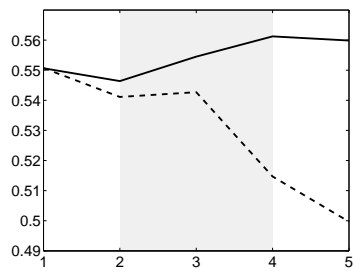

Production

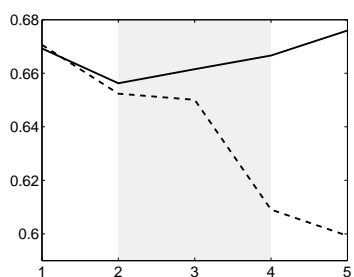

Public Consumption

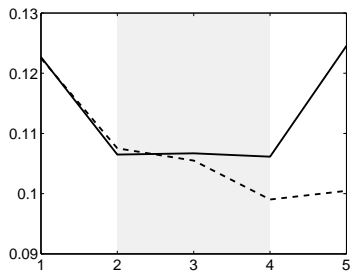

Labor

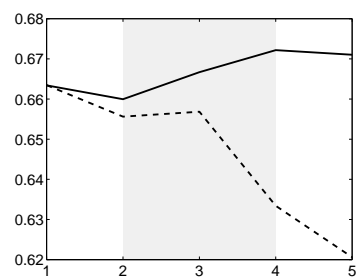

Debt

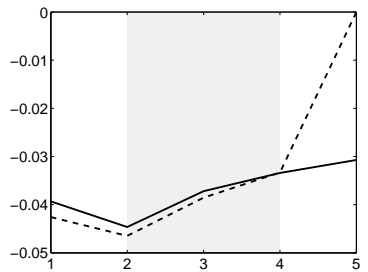

Tax

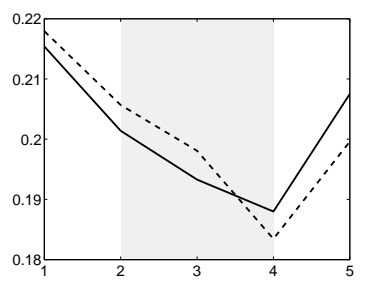

Spread

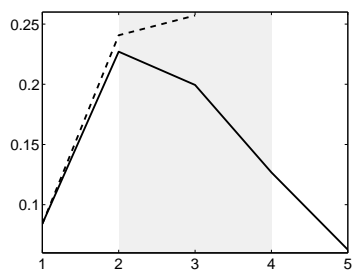

Figure 4: Dynamics During Conditionality; The figures assume the benchmark calibration and plot the average patterns of the macroeconomic variables in the course of conditional bailout arrangements that have a duration of 3 quarters. Horizontal axis: quarters; vertical axis: units. Quarter 1 denotes the quarter before the government enters the conditional bailout program while in quarter 5 the program is abandoned. The shaded area refers to the time in conditionality. The solid line refers to those cases where the government exits the conditional program to be sovereign and unrestricted in its fiscal policies. The dashed line refers to those cases where the government exits the arrangement by defaulting on its external debt.
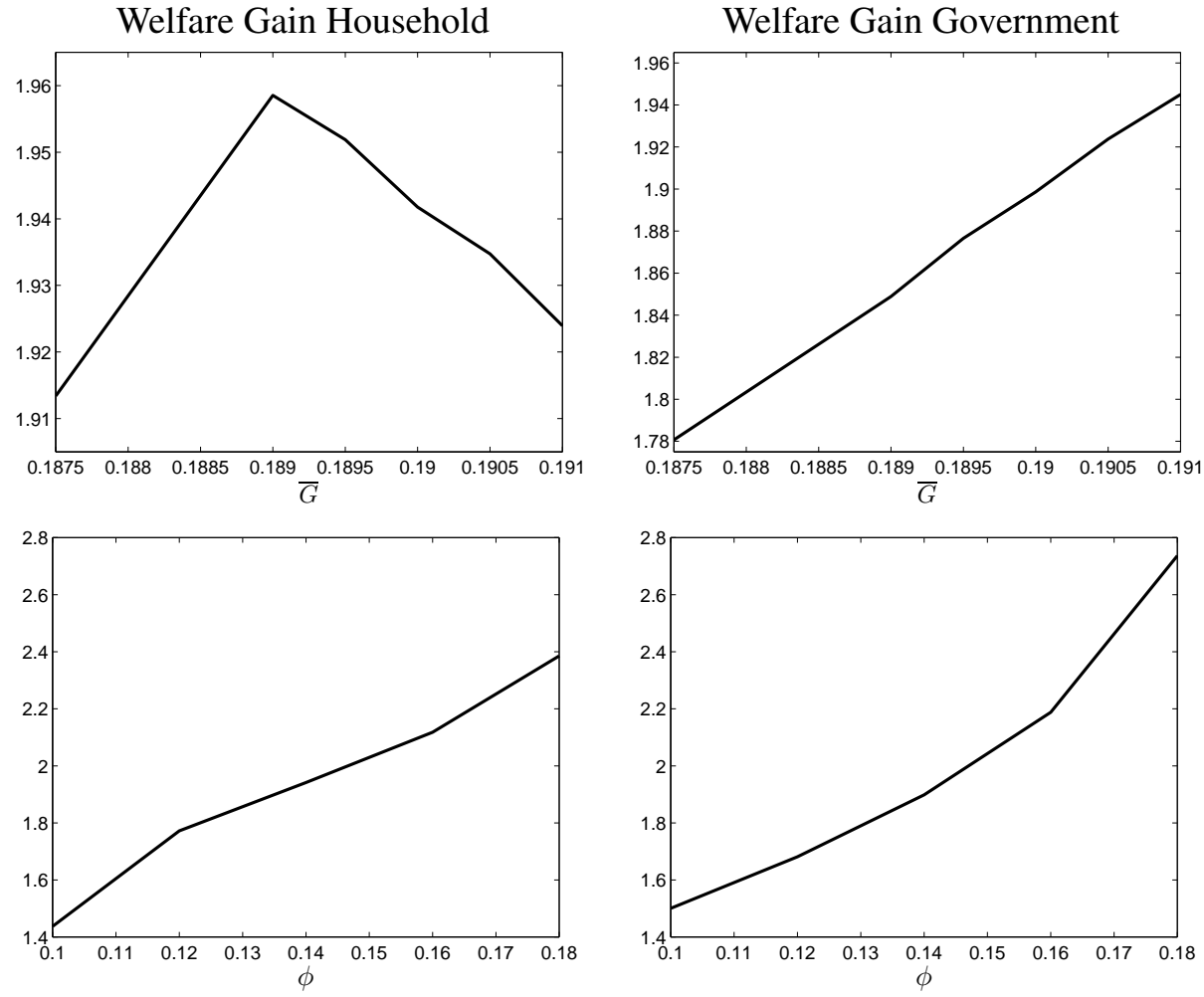

Figure 5: Welfare Gains; First row, horizontal axis: $\bar{G}$; second row, horizontal axis: $\phi$; vertical axis: compensation parameters $\Delta^{h}$ and $\Delta^{g}$ in percent and calculated according to equations (16) and (17), respectively. 